\title{
Development and evaluation of xanthan gum-facilitated ethyl cellulose microsponges for controlled percutaneous delivery of diclofenac sodium
}

\author{
SABYASACHI MAITI ${ }^{1 *}$ \\ SANTANU KAITY ${ }^{1}$ \\ SOMASREE RAY ${ }^{1}$ \\ BISWANATH SA ${ }^{2}$ \\ ${ }^{1}$ Department of Pharmaceutics \\ Gupta College of Technological Sciences \\ Ashram More, G.T. Road, Asansol-713301 \\ West Bengal, India \\ 2 Department of Pharmaceutical \\ Technology, Jadavpur University \\ Kolkata-700032, West Bengal, India
}

Accepted June 8, 2011

\begin{abstract}
In this study, xanthan gum-facilitated ethyl cellulose microsponges were prepared by the double emulsification technique and subsequently dispersed in a carbopol gel base for controlled delivery of diclofenac sodium to the skin. Scanning electron microscopy revealed the porous, spherical nature of the microsponges. Increase in the drug/ polymer ratio $(0.4: 1,0.6: 1,0.8: 1, \mathrm{~m} / \mathrm{m})$ increased their yield (79.1-88.5\%), drug entrapment efficiency (50.0$64.1 \%$ ), and mean particle diameter (181-255 $\mu \mathrm{m})$. Compared to the microsponges with high drug/polymer ratio $(0.8: 1, m / m)$, the flux of entrapped drug through excised rat skin decreased by $19.9 \%$ and $17.0 \%$, respectively, for the microsponges prepared at low and intermediate drug/polymer ratios. When an equivalent amount of pure drug (not entrapped into microsponges) was dispersed into the gel base and the flux was compared, the microsponges (drug/polymer ratio $0.8: 1, \mathrm{~m} / \mathrm{m}$ ) were found to reduce the flux by $33.3 \%$. Whether the drug was dispersed either in un-entrapped or entrapped form into the gel base, the drug permeation through rat skin followed Higuchi's diffusion kinetic model. The microsponges prepared at the lowest drug/polymer ratio exhibited a comparatively slower drug permeation profile and were hence considered most suitable for controlled drug delivery application. FTIR spectroscopy and DSC analyses indicated the chemically stable, amorphous nature of the drug in these microsponges. The gel containing these optimized microsponges was comparable to that of a commercial gel formulation and did not show serious dermal reactions. Hence, the microsponge system obtained at the lowest drug/polymer ratio could be useful for controlled release of diclofenac sodium to the skin.
\end{abstract}

Keywords: W/O/W emulsion, microsponge, diclofenac sodium, xanthan gum, ethyl cellulose, percutaneous delivery

\footnotetext{
* Correspondence; e-mail: sabya245@rediffmail.com
} 
Controlled release of drugs into the epidermis with assurance that the drug remains primarily localized and does not enter the systemic circulation in significant amounts is the area of the present research (1). The conventional topical dosage forms like ointments, lotions, creams or pastes typically provide active ingredients in relatively high concentrations but this may lead to a cycle of short-term overmedication followed by long-term undermedication $(2,3)$. The fundamental appeal of the microsponge technology stems from the difficulty experienced with conventional formulations in releasing active ingredients over an extended period of time.

Microsponges are porous polymeric microparticles and each particle consists of a myriad of interconnected voids within a non-collapsible structure. They are usually between 5 and $300 \mu \mathrm{m}$ in diameter. Microsponges are used as topical drug carriers that allow an even and sustained rate of release and therefore reduce irritation while maintaining efficacy $(4,5)$. In addition, the microsponge particles themselves are too large to be absorbed into the skin and this adds a measure of safety to the microsponge materials (2).

Diclofenac sodium is a non-steroidal anti-inflammatory drug (NSAID) that possesses additional antibacterial activity (6). Systemic use of NSAIDs is severely hampered by gastric and peptic ulcers. Percutaneous delivery of NSAIDs has the advantages of avoiding gastric and peptic ulcers and delivering the drug to the inflammation site. Considering the fact that most inflammatory diseases occur locally and near the surface of the body, percutaneous application of NSAIDs onto the inflamed site can offer the advantage of delivering a drug directly to the site of disease and producing a local effect (7).

In the liquid-liquid suspension polymerization technique (8), most of the active pharmaceutical compounds would decompose at the polymerization temperature. Again, the microsponges obtained by the quasi-emulsion solvent diffusion technique (5) have been criticized for their poor surface morphology. Thus, the objective of this investigation was to prepare diclofenac sodium-loaded ethyl cellulose microsponges by a novel $\mathrm{W} / \mathrm{O} / \mathrm{W}$ emulsion-solvent evaporation technique and to evaluate them. The controlled drug delivery potential of these microsponges was investigated following their incorporation into a carbopol gel base.

\section{EXPERIMENTAL}

\section{Materials}

Diclofenac sodium was a gift from Microlabs, India. Ethyl cellulose (18-22 cps viscosity grade), Carbopol 940, triethanolamine and Span 80 were purchased from Loba Chemie Pvt. Ltd., India.

Xanthan gum was obtained as a gift sample from Sun Pharmaceuticals Industries Ltd., India. It is a natural polysaccharide and is not directly soluble in most organic solvents. Before use, the gum was washed thoroughly with methanol for $4 \mathrm{~h}$ and dried.

Dichloromethane and Tween 80 were supplied by Merck Ltd., India. Voveran Emulgel (diclofenac sodium, $1 \% \mathrm{~m} / \mathrm{m}$ ), a gel marketed by Novartis India Ltd., India, was used for comparison with the microsponge-loaded gel. All other reagents obtained commercially were of analytical grade and used as received. 
S. Maiti et al:: Development and evaluation of xanthan gum-facilitated ethyl cellulose microsponges for controlled percutaneous delivery of diclofenac sodium, Acta Pharm. 61 (2011) 257-270.

\section{Preparation of microsponges by the modified multiple emulsion technique}

The microsponges were prepared by the xanthan gum facilitated $\mathrm{W} / \mathrm{O} / \mathrm{W}$ emulsion solvent evaporation technique. A hundred milligrams of diclofenac sodium were dissolved in $8 \mathrm{~mL}$ of doubly distilled water and then $2 \mathrm{~mL}$ of acetone was added to the solution. Xanthan gum was dispersed slowly into the acetone/water mixture to obtain a concentration of $0.2 \%(\mathrm{~m} / \mathrm{V})$. Up to $40-50 \%$ of acetone can be added to an aqueous solution of xanthan gum without precipitation of the gum. For this reason, xanthan gum was used in this novel process. This internal aqueous phase was emulsified into a $25 \mathrm{~mL}$ $1 \%(\mathrm{~m} / \mathrm{V})$ solution of ethyl cellulose in dichloromethane containing $0.5 \%(\mathrm{~m} / \mathrm{V})$ Span 80 using a rotor-stator homogenizer (Model RQ-127A, Remi Motors Ltd., India) for 5 min at $2000 \mathrm{rpm}$. The resulting water-in-oil (W/O) emulsion was then transferred into $60 \mathrm{~mL}$ of water containing $0.6 \%(\mathrm{~m} / \mathrm{V})$ Tween 80 under continuous mechanical stirring at $1300 \mathrm{rpm}$ to form a $\mathrm{W} / \mathrm{O} / \mathrm{W}$ type emulsion. The stirring was continued with a three-blade propeller for a period of $1.5 \mathrm{~h}$ to allow evaporation of the organic solvent. The resulting microsponges were separated by filtration and finally air-dried.

The following processing variables were investigated: ratios of acetone/water 2:8; 5:8 and 8:8 $(\mathrm{V} / \mathrm{V})$ and drug/polymer (ethyl cellulose) ratios: 0.4:1, 0.6:1 and 0.8:1 $(\mathrm{m} / \mathrm{m})$. The same method was adopted for the preparation of blank microsponges (without drug) under two different sets of conditions: one was made using the acetone/water ratio of $0: 10$ and the other using $10 \mathrm{~mL}$ of acetone/water mixture $(2: 8)$ in the internal aqueous phase.

\section{Scanning electron microscopy (SEM)}

The blank and drug-loaded microsponges were examined under a scanning electron microscope (JEOL-JSM-6360, Japan). SEM photographs of uncoated samples were taken at an acceleration voltage of $20 \mathrm{kV}$ and at a chamber pressure of $79.99 \mathrm{~Pa}$. The dried samples were placed on NEM TAPE adhesive paper and photographed.

\section{Drug entrapment efficiency}

Accurately weighed $20 \mathrm{mg}$ of drug-loaded ethyl cellulose microsponges were dissolved in $2 \mathrm{~mL}$ dichloromethane, $30 \mathrm{~mL}$ of $\mathrm{pH} 7.4$ phosphate buffer solution was added and the mixture was heated at $50-55{ }^{\circ} \mathrm{C}$ for $45 \mathrm{~min}$ in a thermostatic water bath to remove dichloromethane. After that, the volume was adjusted to $50 \mathrm{~mL}$ with the same fresh buffer heated at $50-55^{\circ} \mathrm{C}$. The solution was cooled, filtered, diluted and analyzed spectrophotometrically (UV1, Thermo-spectronic, UK) at $276 \mathrm{~nm}$ using phosphate buffer ( $\mathrm{pH}$ 7.4) as blank. The drug content and drug entrapment efficiency of the microsponges were calculated. Each experiment was carried out in triplicate. Reliability of this method was assessed by conducting a recovery analysis using known amounts of the drug with or without polymer; recovery averaged $98.2 \pm 0.8 \%$.

\section{Particle size analysis}

Particle size studies were carried out using a Mastersizer 2000 Ver.5.40 (Malvern Instruments Ltd., UK) which allows sample measurement in the range of $0.020-2000 \mu \mathrm{m}$. 
S. Maiti et al.: Development and evaluation of xanthan gum-facilitated ethyl cellulose microsponges for controlled percutaneous delivery of diclofenac sodium, Acta Pharm. 61 (2011) 257-270.

The particles were dispersed in water and the size was measured using the laser light scattering technique. Polydispersity index was determined according to the equation (9):

$$
\text { polydispersity }=[d(0.9)-d(0.1)] / d(0.5)
$$

where $d(0.9)$ corresponds to the particle size immediately above $90 \%$ of the sample, $d(0.5)$ corresponds to the particle size immediately above $50 \%$ of the sample; $d(0.1)$ corresponds to the particle size immediately above $10 \%$ of the sample.

\section{Preparation of the gel base and of unentrapped drug-and microsponge-loaded gels}

About $1 \mathrm{~g}$ of Carbopol 940 was mixed with $5 \mathrm{~g}$ of glycerin and a paste was made. Then $95 \mathrm{~mL}$ of water was added slowly to the paste under constant stirring. Finally, triethanolamine was added dropwise to adjust the $\mathrm{pH}$ to 6.5-7.5.

The unentrapped drug-loaded gel was prepared by dissolving $9.01 \mathrm{mg}$ of diclofenac sodium in $4 \mathrm{~g}$ of gel base. In contrast, accurately weighed $66.67 \mathrm{mg}$ of each microsponge preparation having a different drug/polymer ratio was mixed gently and separately with the gel base to obtain $4 \mathrm{~g}$ of microsponge-loaded gel.

\section{Concentration uniformity of unentrapped drug- and microsponge-loaded gels}

Accurately weighed $4 \mathrm{~g}$ of microsponge-loaded gel was dried at a temperature of $50{ }^{\circ} \mathrm{C}$ for $24 \mathrm{~h}$ and $2 \mathrm{~mL}$ dichloromethane was added to the dried gel under continuous stirring to dissolve the microsponges. Following addition of $50 \mathrm{~mL}$ phosphate buffer ( $\mathrm{pH} 7.4$ ) to the dried gel, it was heated to $50-55{ }^{\circ} \mathrm{C}$ to evaporate the organic solvent. The solution was filtered, diluted with the buffer solution and analyzed at $276 \mathrm{~nm}$. The drug concentration in an unentrapped drug-loaded gel formulation was assessed similarly, except that no dichloromethane was added. Each experiment was carried out in triplicate and the mean of three observations was reported.

\section{Skin permeation and irritation}

Approval to carry out these studies was obtained from the Institutional Animal Ethics Committee (IAEC) (955/A/06/CPCSEA) of the Gupta College of Technological Sciences, Asansol, India.

Male Wistar rats were anesthetized, sacrificed and the abdominal skin was excised. Hairs on the rat skin were removed, defatted and the dermis side was wiped with isopropyl alcohol to remove residual adhering fat. The skin was washed with distilled water and preserved at $-20{ }^{\circ} \mathrm{C}$ for further use.

In vitro permeation studies were performed using a Franz diffusion cell to quantify the drug diffused through excised skin from the microsponges-loaded gel formulation.

The diffusion cell had the receptor compartment volume of $32 \mathrm{~mL}$ and an effective diffusion area of $2.54 \mathrm{~cm}^{2}$. A predetermined amount of gel sample $(2 \mathrm{~g})$ was placed on the donor side. The receptor medium containing phosphate buffer ( $\mathrm{pH} 7.4)$ was continuously stirred at $600 \mathrm{rpm}$ and thermostatted at $37 \pm 1^{\circ} \mathrm{C}$ with a circulating jacket. At pre- 
S. Maiti et al:: Development and evaluation of xanthan gum-facilitated ethyl cellulose microsponges for controlled percutaneous delivery of diclofenac sodium, Acta Pharm. 61 (2011) 257-270.

determined time intervals, $2-\mathrm{mL}$ samples were withdrawn from the receiver compartment and replenished with an equal volume of fresh buffer. The collected samples were analyzed at $276 \mathrm{~nm}$. In vitro diffusion study of unentrapped drug-loaded gel formulation was carried out under similar experimental conditions. Each experiment was carried out in triplicate.

Six male Wistar rats with undamaged skin, 2-3 months old, 150-210 g body mass, were used for testing skin irritation of the optimized microsponge-loaded gel formulation. Hair was shaved from the back of each animal and an area of $4 \mathrm{~cm}^{2}$ was marked on both sides; one side served as the control and the other as test. Gel was applied (2.5 g $\mathrm{kg}^{-1}$ body mass) each day. Water was used to remove the test substance adhering to the skin at the end of each exposure period.

The degree of erythema or edema was scored visually as per the Draize evaluation of dermal reactions for 7 days. The primary irritation index (PII) was calculated based on the total scored reactions divided by 48 (four scoring intervals multiplied by two test parameters multiplied by six rats). According to the draize evaluation, a PII value of zero indicates no irritation, a value between 0.04-0.99 indicates barely perceptible irritation, and that between 1.00-1.99 indicates slight irritation.

\section{Kinetic modeling}

To understand the drug permeation kinetics from microsponge-loaded gel formulations, the data was fitted into zero-order (cumulative percentage drug permeated vs. time), first-order (log cumulative percentage drug remaining to be permeated vs. time) and Higuchi's model equations (10), and analyzed by linear regression.

\section{Comparative evaluation of microsponge-loaded gel and commercial gel}

pH. - The $\mathrm{pH}$ was read by a digital $\mathrm{pH}$ meter (Systronics, India) after suitable dilution.

Spreadability and consistency. - One gram of gel was placed between two glass slides: the lower slide was fixed and $1 \mathrm{~g}$ load was applied to the upper slide. The time in seconds taken by the upper slide to slip off the gel and travel a distance of $6 \mathrm{~cm}$ was recorded using a stop watch and the spreading value was then calculated (11).

The consistency of gel formulations was measured by the method reported earlier (12).

Syneresis. - A known amount of the gel formulations were subjected to an environment of $25{ }^{\circ} \mathrm{C} / 60 \pm 5 \% \mathrm{RH}$ for one month, and the percentage of water oozed out was calculated.

\section{Fourier transform infrared (FTIR) spectroscopy}

FTIR spectra of pure diclofenac sodium, physical mixture of diclofenac sodium/ethyl cellulose/xanthan gum (1:2.5:0.2) and optimized microsponge formulation were recorded with a Perkin Elmer FTIR Spectrometer (Spectrum RX1, USA) from $4000-400 \mathrm{~cm}^{-1}$ using $\mathrm{KBr}$ pellets. The pellets were made by applying a pressure of $100 \mathrm{~kg} \mathrm{~cm}^{-2}$ to a mixture of polymers and $\mathrm{KBr}$ (1:20) for $10 \mathrm{~min}$ in a hydraulic press (KP, Kimaya Engineers, India). 
S. Maiti et al.: Development and evaluation of xanthan gum-facilitated ethyl cellulose microsponges for controlled percutaneous delivery of diclofenac sodium, Acta Pharm. 61 (2011) 257-270.

\section{Differential scanning calorimetry (DSC)}

DSC thermograms of pure diclofenac sodium, physical mixture of diclofenac sodium/ethyl cellulose/xanthan gum (1:2.5:0.2) and optimized microsponge formulation were recorded using a Perkin-Elmer instrument (Pyris Diamond TG-DTA, Singapore). Each sample (3-7 mg) was accurately weighed into a $50-\mu \mathrm{L}$ aluminium pan under hermetically sealed conditions. The measurements were performed in nitrogen atmosphere $(50 \mathrm{~mL} \mathrm{~min}-1)$ between 30 and $500{ }^{\circ} \mathrm{C}$ at a heating rate of $10{ }^{\circ} \mathrm{C} \mathrm{min}-1$.

\section{Statistical analysis}

The drug entrapment efficiency of the microsponges, prepared as a function of the drug/polymer weight ratio were subjected to one-way analysis of variance (ANOVA). Each experimental data was represented as mean with their standard deviation.

\section{RESULTS AND DISCUSSION}

\section{Formation of microsponges}

In the fabrication of microsponges, xanthan gum dispersion in an acetone/water mixture (2:8) was emulsified with ethyl cellulose solution in dichloromethane to form a W/O type emulsion. During primary emulsification, the acetone and dichloromethane mixed instantly at the interface of the droplets. Transfer of this emulsion into an external aqueous phase produced a $\mathrm{W} / \mathrm{O} / \mathrm{W}$ emulsion and the organic solvents diffused slowly from the droplet surface. Upon complete removal of the organic solvents via diffusion, the finely dispersed polymer droplets were solidified creating porous microparticles, termed microsponges (Fig. 1a) (13). In contrast, no porous particles were produced if no acetone was used (Fig. 1b). Xanthan gum imparted non-collapsible characteristics to the microsponges.

Different acetone/water $(V / V)$ ratios $(2: 8,5: 8$ and 8:8) were tested for the preparation of microsponges setting the drug/polymer ratio at 0.4:1 $(\mathrm{m} / \mathrm{m})$. Scanning electron microscopy revealed that all the microsponges were porous, spherical but the porous nature was more prominent at an acetone/water ratio of 2:8 (Figs. 1c-d) and no drug crystals were visible on the microsponge surface at this ratio. Further increase in acetone/ water ratio crowded the microsponge surface with drug crystals (Fig. 1e).

The higher the volume of acetone, the higher was the solvent drag for diffusion and accordingly the temperature of the emulsion system fell. It was hypothesized that with the increase in solvent ratio, the precipitation of polymer solution droplets gradually became slower, allowing more time for solvent diffusion and subsequent deposition of drug crystals on the particle surface. Though this phenomenon was not noticeable at the acetone/water ratio of 2:8 $(\mathrm{V} / \mathrm{V})$, this was evident at ratios of 5:8 and 8:8 $(\mathrm{V} / \mathrm{V})$. Hence, no further investigations were carried out at higher volume ratios and the acetone/water ratio of 2:8 $(V / V)$ was chosen for further investigation. 

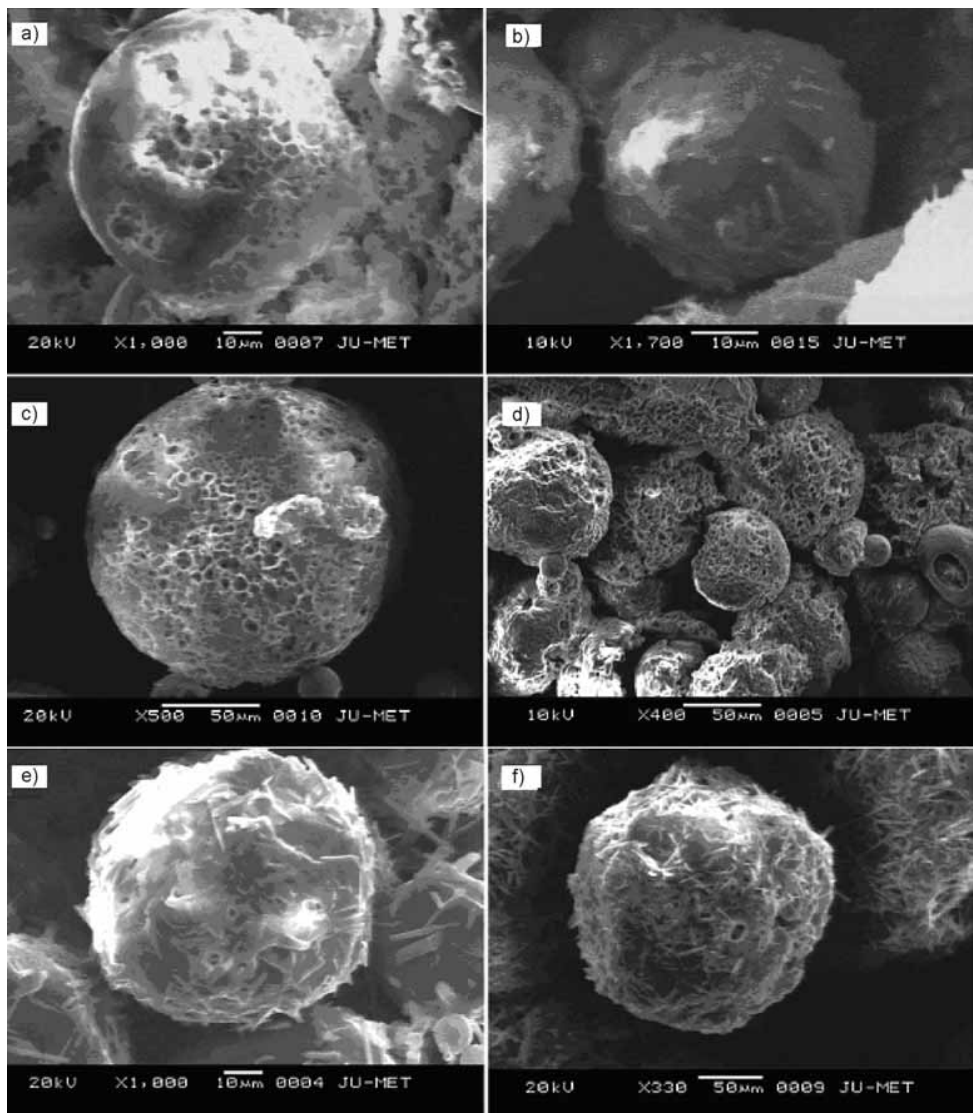

Fig. 1. Scanning electron micrographs of the particles under different preparative conditions: blank microsponges: a) acetone/water ratio 2:8 $(V / V)$, b) acetone/water ratio 0:10 $(V / V)$, microsponges with drug/polymer ratio 0.4:1 $(\mathrm{m} / \mathrm{m})$ : c) individual photograph at acetone/water ratio 2:8 $(\mathrm{V} / \mathrm{V})$, d) group photograph at acetone/water ratio 2:8 $(\mathrm{V} / \mathrm{V})$, e) acetone/water ratio 8:8 $(\mathrm{V} / \mathrm{V})$, and f) acetone/water ratio $2: 8(\mathrm{~V} / \mathrm{V})$ with drug/polymer ratio $0.8: 1(\mathrm{~m} / \mathrm{m})$.

\section{Size, surface morphology and drug entrapment efficiency}

To investigate possible modifications of microsponge properties, the drug/polymer ratio was varied: $0.4: 1$ to $0.6: 1$ and $0.8: 1(\mathrm{~m} / \mathrm{m})$. Electron micrographs showed that the microsponges were spherical in shape and the surface contained pores. Increase in the drug to polymer ratio resulted in the formation of drug crystals over particle surfaces (Fig. 1f). It is easily deducible from the earlier hypothesis that at higher drug/polymer ratios, more drugs will reach the surface of the nascent microsponges being dissolved in the solvents during diffusion. Moreover, as the diffusion of solvents becomes slower with the increase in drug/polymer ratio, there is more time for the formation of drug crystals. Orlu et al. (5) reported similar findings with flurbiprofen microsponges. 
S. Maiti et al:: Development and evaluation of xanthan gum-facilitated ethyl cellulose microsponges for controlled percutaneous delivery of diclofenac sodium, Acta Pharm. 61 (2011) 257-270.

The production yield, drug entrapment efficiency and mean particle size increased with the increase in the drug/polymer ratio (Table I). At higher drug/polymer ratios, the rate of solvent diffusion from the internal to organic phase decreased due to higher viscosity of the internal phase. This provided more time for droplet formation and improved the yield of microsponges (14). At all drug/polymer ratios employed, the mean amount of drug entrapped in the microsponges was lower than the theoretical value because the drug loading efficiency did not reach $100 \%$. This can be attributed to dissolution of some drug in the aqueous phase. With the increase in the drug/polymer ratio, the drug loading efficiency gradually increased (Table I) and the difference was statistically significant $(p<0.05)$. Particle size of the microsponges was directly proportional to the apparent viscosity of the internal aqueous phase. When the dispersed phase was poured into the dispersion medium, bigger droplets were formed (15), and the mean particle size increased at higher drug/polymer ratios (Table I). The higher the polydispersity index, the wider was the particle size distribution. Hence, it was clear that the microsponges had a wide size distribution at all drug/polymer ratios because the polydispersity index ranged from 2.394 to 2.993 (Fig. 2).

\section{Gel formulations and skin permeation behaviors}

The microsponges prepared with different drug/polymer ratios were incorporated into carbopol gel base and gel formulations were evaluated. Theoretically, the average drug loading in the microsponges was $0.22,0.34$ and $0.45 \%(\mathrm{~m} / \mathrm{m})$, respectively, for drug/polymer ratios of $0.4: 1,0.6: 1$, and $0.8: 1(\mathrm{~m} / \mathrm{m})$. When gels were evaluated, their drug loading was in the order of $0.22 \pm 0.02,0.32 \pm 0.01$ and $0.44 \pm 0.02 \%(\mathrm{~m} / \mathrm{m})$, respectively. RSD values of 3-9\% indicate that the microsponges were uniformly dispersed in the gel base. The cumulative amount of drug permeated per unit skin surface area $(Q)$ from the microsponge-loaded gel formulations was plotted against time (Fig. 3). The $Q$ value increased at higher ratios due to an increase in the active ingredient concentration in the formula. Besides, the microsponges exhibited a burst effect within $0.5 \mathrm{~h}$ in their skin permeation profile at drug/polymer mass ratios of 0.6:1 and 0.8:1. After that, a linear relationship existed between $Q$ and time (see $R^{2}$ value in Table I). The burst effect ob-

Table I. Effect of the drug/polymer ratio on the yield, drug entrapment efficiency (DEE), mean particle size and polydispersity index (PDI), and on the permeation of diclofenac sodium from the microsponge-loaded gel formulation through excised rat skin

\begin{tabular}{cccccccc}
\hline $\begin{array}{c}\text { Drug/polymer } \\
(m / m)\end{array}$ & $\begin{array}{c}\text { Yield } \\
(\%)\end{array}$ & $\begin{array}{c}\text { DEE } \\
(\%)^{\mathrm{a}}\end{array}$ & $\begin{array}{c}\text { Size, } d_{50 \%} \\
(\mu \mathrm{m})\end{array}$ & PDI & $\begin{array}{c}\text { Flux } \\
\left(\mathrm{mg} \mathrm{cm}^{-2} \mathrm{~h}^{-1}\right)^{\mathrm{b}}\end{array}$ & $R^{2 \mathrm{c}}$ & $\begin{array}{c}\mathrm{Q}_{8} \\
\left(\mathrm{mg} \mathrm{cm}^{-2}\right)^{\mathrm{d}}\end{array}$ \\
\hline $0.4: 1$ & 79.1 & $50.0 \pm 3.4$ & 181.772 & 2.801 & 0.0306 & 0.9427 & 0.3666 \\
$0.6: 1$ & 83.4 & $57.9 \pm 0.6$ & 215.156 & 2.993 & 0.0317 & 0.9402 & 0.3920 \\
$0.8: 1$ & 88.5 & $64.1 \pm 1.4$ & 255.642 & 2.394 & 0.0382 & 0.9668 & 0.4622 \\
\hline
\end{tabular}

a Mean $\pm \mathrm{SD}, n=3$.

b Flux was obtained by regression analysis from slopes of the linear portion of the amount of drug released per unit surface area vs. time plot.

${ }^{c}$ Coefficient of determination.

${ }^{\mathrm{d}} \mathrm{Q}_{8}$ is the amount of drug permeation per unit surface area after $8 \mathrm{~h}$. 
Fig. 2. Particle size distribution of drug-loaded ethyl cellulose microsponges prepared at drug/ polymer ratio of $0.4: 1(\mathrm{~m} / \mathrm{m})$.

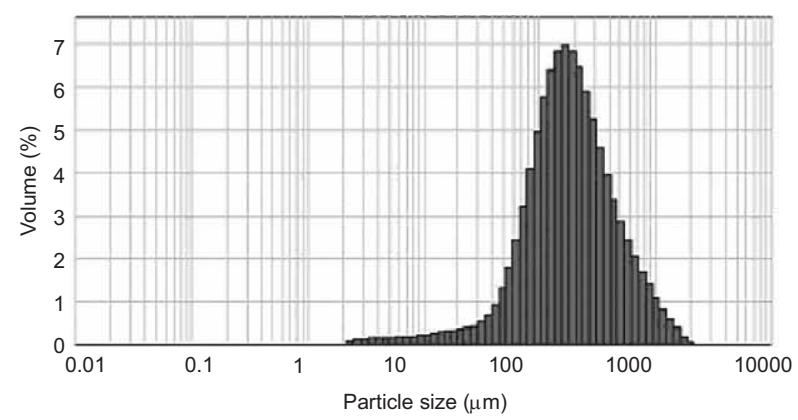

served at higher mass ratios could be due to two reasons: the first was the fact that drug was close to the surface, or on the surface of the microsponges, and the second was the well known porous nature of microsponges, the pores providing channels for drug release (16). This fact was corroborated by scanning electron micrographs of the microsponges that indicated the presence of non-encapsulated drug over the surfaces (Fig. 1f). When the free drug was released, the flux remained constant for the following $7.5 \mathrm{~h}$. The slopes of the linear portion (obtained after $0.5 \mathrm{~h}$ ) of the permeation profiles were estimated as a steady-state flux of the drug from the gel formulations. The flux of the drug was comparatively slower for microsponges having a drug/polymer ratio $(04: 1, \mathrm{~m} / \mathrm{m})$ and this slower flux indicated the release of entrapped drug from the microsponges (Table I). The amount of drug permeated through unit area after $8 \mathrm{~h}\left(Q_{8}\right.$ value) was also found lower at this ratio (Table I). This result was consistent with the report of K1liçarslan and Baykara (17). They reported that as the amount of polymer increased, the matrix wall of microsponges became thicker and, consequently, led to a slower drug release rate.

In vitro drug permeation from all the microsponge-loaded gel formulations could be best described by Higuchi's diffusion kinetics as the plot of cumulative percentage drug permeated vs. square root of time was found to be linear with $R^{2}$ values ranging from 0.9797 to 0.9889 (Table II). Similar release kinetics was observed for mupirocin from the microsponge-based emulgel system (3). As the microsponges provided a slower and extended drug permeation profile at a drug/polymer ratio of $0.4: 1(\mathrm{~m} / \mathrm{m})$, the gel formulation containing these microsponges was considered to be an optimized formulation.

Fig. 3. Effect of the drug/polymer ratio on the amount of drug permeation per unit area of rat skin from gel formulations containing microsponges: Drug/polymer ratio $(m / m):(\boldsymbol{\Delta}) 0.8: 1$, $(\triangle) 0.6: 1$, (ם) 0.4:1. Mean \pm SD, $n=3$.

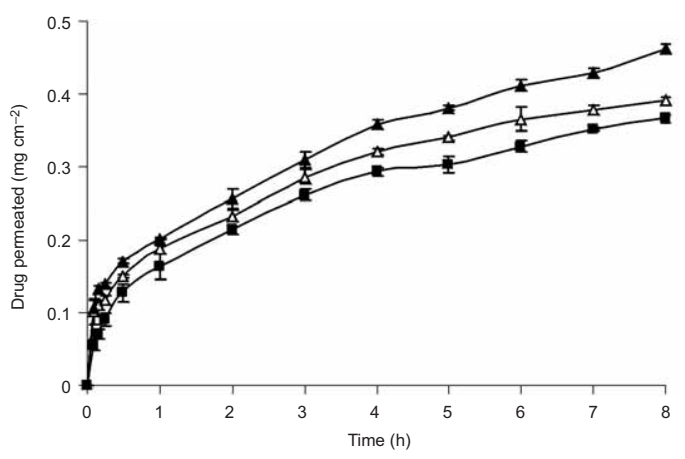


S. Maiti et al.: Development and evaluation of xanthan gum-facilitated ethyl cellulose microsponges for controlled percutaneous delivery of diclofenac sodium, Acta Pharm. 61 (2011) 257-270.

Table II. Effect of the drug/polymer ratio on the permeation kinetics of diclofenac sodium from the microsponge-loaded gel formulation through excised rat skin

\begin{tabular}{ccccccc}
\hline \multirow{2}{*}{$\begin{array}{c}\text { Drug/polymer } \\
(m / m)\end{array}$} & \multicolumn{2}{c}{ Zero-order } & \multicolumn{2}{c}{ First-order } & \multicolumn{2}{c}{ Higuchi } \\
\cline { 2 - 7 } & $R^{2}$ & $\begin{array}{c}k_{0} \\
\left(\% \mathrm{~h}^{-1}\right)^{\mathrm{a}}\end{array}$ & $R^{2}$ & $\begin{array}{c}k_{1} \\
\left(\mathrm{~h}^{-1}\right)^{\mathrm{a}}\end{array}$ & $R^{2}$ & $\begin{array}{c}k_{\mathrm{H}} \\
\left(\% \mathrm{~h}^{-1 / 2}\right)^{\mathrm{a}}\end{array}$ \\
\hline $0.4: 1$ & 0.8902 & 2.3053 & 0.9070 & 0.0114 & 0.9889 & 7.1328 \\
$0.6: 1$ & 0.8778 & 1.5298 & 0.8906 & 0.0073 & 0.9797 & 4.7444 \\
$0.8: 1$ & 0.8993 & 1.3399 & 0.9100 & 0.0063 & 0.9843 & 4.1152 \\
\hline
\end{tabular}

a $k_{0}, k_{1}$ and $k_{\mathrm{H}}$ are the release rate constants for zero-order, first-order and Higuchi model, respectively.

After that, this optimized gel formulation was compared to that of the unentrapped drug-loaded gel formulation. The permeation profiles of these two formulations, containing equivalent amounts of the drug, are displayed in Fig. 4. Comparatively higher flux (0.0573 $\mathrm{mg} \mathrm{cm}^{-2} \mathrm{~h}^{-1}$ with correlation coefficient of 0.9686$)$ was achieved for the gel formulation containing unentrapped drug. However, the drug permeation kinetics was the same and followed Higuchi's diffusion model $\left(R^{2}=0.9928\right)$. Hence, it was obvious that drug permeation became slower when the drug was added to the gel in entrapped form rather than in unentrapped form.

In order to comply with other relevant properties of a gel such as $\mathrm{pH}$, spreading value, consistency and syneresis, the optimized microsponge-loaded gel formulation was compared with a commercial gel. The data conformed well to those obtained with the commercial gel (Table III).

Freeze-thaw cycling did not alter the white appearance and $\mathrm{pH}$ of the optimized gel formulation ( $\mathrm{pH}$ 7.20). The drug content determined after freeze-thaw cycling was found to be $0.20 \pm 0.01 \%(\mathrm{~m} / \mathrm{m})$ and was quite close to the actual content of the optimized formulation.

The scores for erythema and edema on the first, third, fifth and seventh day were totaled for all rats. The PII was found to be 0.08. According to Draize, the optimized microsponge-loaded gel formulation acted as a barely perceptible irritant to the rat skin.

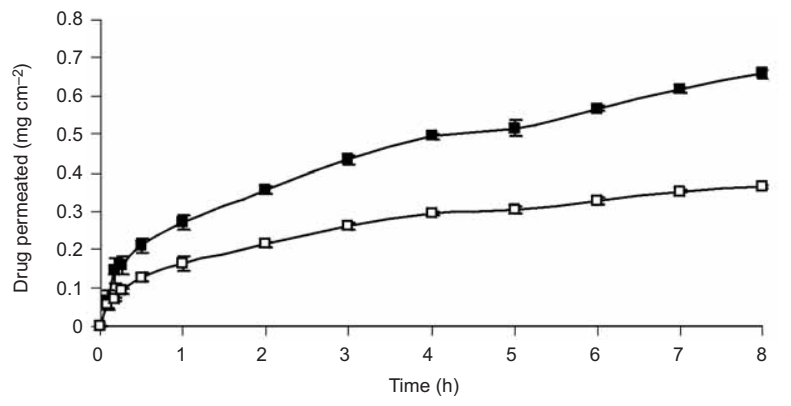

Fig. 4. Comparative drug permeation profiles of: (ם) unentrapped drug or free drug-loaded, gel and $(\square)$ optimized microsponge-loaded gel. Mean $\pm \mathrm{SD}, n=3$. 
S. Maiti et al:: Development and evaluation of xanthan gum-facilitated ethyl cellulose microsponges for controlled percutaneous delivery of diclofenac sodium, Acta Pharm. 61 (2011) 257-270.

Table III. Evaluation of gel characteristics for optimized microsponge-loaded gel and commercial gel

\begin{tabular}{lcccc}
\hline & \multicolumn{4}{c}{ Gel characteristics } \\
\cline { 2 - 5 } Formulations & $\mathrm{pH}$ & $\begin{array}{c}\text { Spreadability } \\
\left(\mathrm{g} \mathrm{cm} \mathrm{s}^{-1}\right)\end{array}$ & $\begin{array}{c}\text { Consistency } \\
(\mathrm{mm})\end{array}$ & $\begin{array}{c}\text { Syneresis } \\
(\%, \mathrm{~m} / \mathrm{m})\end{array}$ \\
\hline Commercial gel & 7.54 & 0.1083 & 8.0 & 0.0 \\
Microsponge-loaded gel & 7.20 & 0.0802 & 6.0 & 0.7 \\
\hline
\end{tabular}

\section{Drug-polymer compatibility}

Drug-polymer compatibility in the optimized microsponges was evaluated by FTIR and DSC analysis. The principle IR peaks of pure diclofenac sodium appeared at wavenumbers of $1283.14 \mathrm{~cm}^{-1}$ and $1304.22 \mathrm{~cm}^{-1}$ and they resulted from C-N stretching. The peaks at $1507.81 \mathrm{~cm}^{-1}$ and $1574.81 \mathrm{~cm}^{-1}$ resulted from $\mathrm{C}=\mathrm{C}$ and $\mathrm{C}=\mathrm{O}$ stretching of the carboxylate functional group, respectively (Fig. 5a) (18). These characteristic peaks were identified in the physical mixture (Fig. 5b) as well as in the drug-loaded optimized microsponges (Fig. 5c) with no appreciable changes in frequencies. Thus it can be inferred that there was no chemical interaction between the drug and polymer in optimized microsponges.

Fig. 5. FTIR spectrum of: a) pure diclofenac sodium, b) physical mixture of the drug and other excipients of microsponges, c) optimized drug-loaded microsponges, d) blank microsponges.

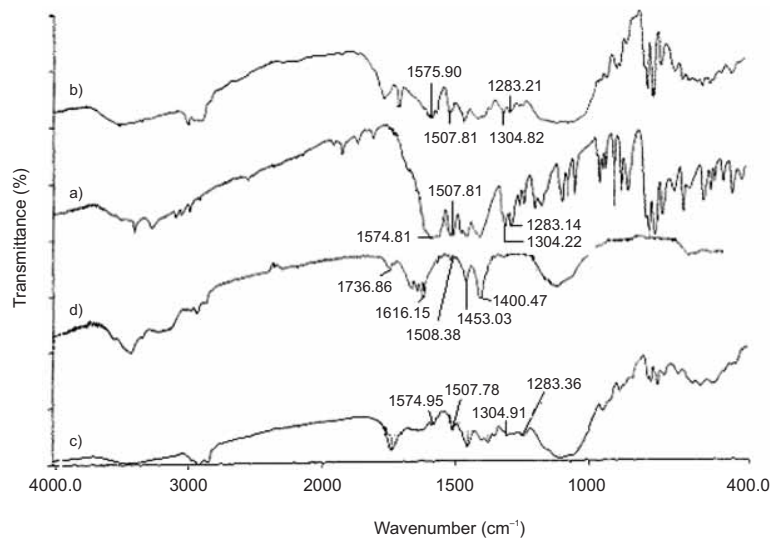

DSC thermogram of pure drug showed two endothermic peaks (Fig. 6). The first small endothermic peak at $42.11^{\circ} \mathrm{C}$ was due to water loss. The other sharp endothermic peak at $279.26{ }^{\circ} \mathrm{C}$ indicated the melting of drug crystals (19). In other words, this result is indicative of melting and decomposition. The normal melting point range of the drug is $283-285{ }^{\circ} \mathrm{C}$. However, neither the physical mixture nor optimized microsponges showed any sharp endothermic peak close to the reported melting point. This clearly indicated that the drug present in these systems remained mostly in amorphous state and was dispersed homogeneously throughout the microsponges. 


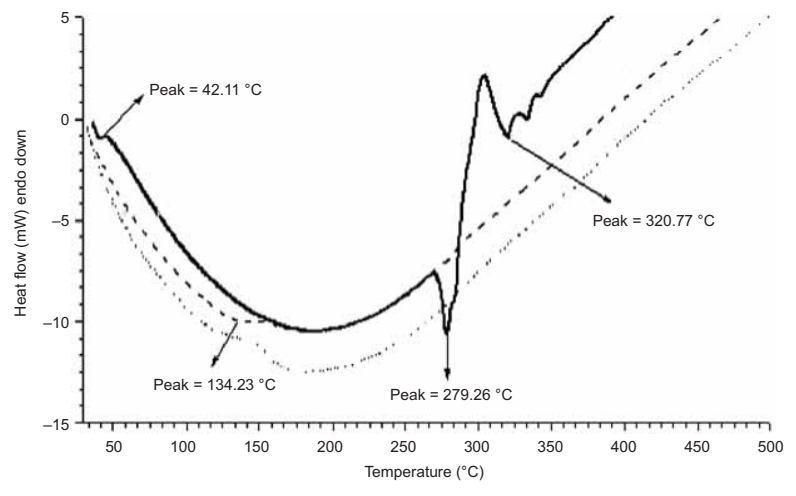

Fig. 6. DSC thermograms of diclofenac sodium (-), physical mixture of the drug and other excipients of microsponges (- - -) and optimized drug-loaded microsponges $(---)$.

\section{CONCLUSIONS}

In this study, ethyl cellulose microsponges containing diclofenac sodium were developed by the xanthan gum-facilitated $\mathrm{W} / \mathrm{O} / \mathrm{W}$ emulsion solvent evaporation technique. The volume of acetone had a key role in the formation of microsponges. The properties of microsponges were greatly affected by the drug/polymer ratio. SEM photographs revealed the spherical nature of the microsponges in all variations; however at higher ratios, drug crystals were observed on the microsponge surface. Depending upon the drug/ polymer ratios, drug entrapment efficiency as high as $64.1 \%$ was achieved for the microsponges. Drug diffusion from the microsponge-loaded gel formulation was slower at the drug/polymer ratio of 0.4:1 $(\mathrm{m} / \mathrm{m})$ than at higher ratios. Hence, the microsponges prepared at the drug/polymer ratio of $0.4: 1(\mathrm{~m} / \mathrm{m})$ were considered most suitable in providing an extended drug permeation profile. Primary skin irritation test revealed that this gel formulation was almost nonirritant to rat skin. Furthermore, the drug was compatible with the polymers of the microsponges. It was thus concluded that the microsponge-loaded gel formulation can be helpful in the treatment of dermal inflammations or localized rheumatic conditions for a longer period of time.

\section{REFERENCES}

1. S. Saxena and S. Nacht, Polymeric Porous Delivery Systems: Polytrap ${ }^{\circledR}$ and Microsponge ${ }^{\circledR}$, in Delivery System Handbook for Personal Care and Cosmetic Products: Technology, Applications and Formulations (Ed. M. R. Rosen), William Andrew Publishing, New York 2005, pp. 333-351.

2. S. Nacht and M. Katz, The Microsponge: A Novel Topical Programmable Delivery System, in Topical Drug Delivery Formulations (Ed. D. W. Osborne and A. H. Amman), Marcel Dekker, New York 1990, pp. 299-325.

3. N. Amrutiya, A. Bajaj and M. Madan, Development of microsponge for topical delivery of mupirocin, AAPS PharmSciTech. 10 (2009) 402-409; DOI: 10.1208/s12249-009-9220-7. 
S. Maiti et al:: Development and evaluation of xanthan gum-facilitated ethyl cellulose microsponges for controlled percutaneous delivery of diclofenac sodium, Acta Pharm. 61 (2011) 257-270.

4. K. Embil and S. Nacht, The microsponge ${ }^{\circledR}$ delivery system (MDS): A topical delivery system with reduced irritancy incorporating multiple triggering mechanisms for the release of actives, J. Microencapsul. 13 (1996) 575-588; DOI: 10.3109/02652049609026042.

5. M. Orlu, E. Cevher and A. Araman, Design and evaluation of colon specific drug delivery system containing flurbiprofen microsponges, Int. J. Pharm. 318 (2006) 103-117; DOI: 10.1016/j. ijpharm.2006.03.025.

6. S. Annadurai, A. Basu, S. Ray, S. G. Dastidar and A. N. Chakrabarty. Antibacterial activity of the anti-inflammatory agent diclofenac sodium, Indian J. Exp. Biol. 36 (1998) 86-90.

7. A. Arellano, S. Santoyo, C. Martin and P. Ygartua, Influence of propylene glycol and isopropyl myristate on the in vitro percutaneous penetration of diclofenac sodium from carbopol gels, Eur. J. Pharm. Sci. 7 (1999) 129-135; DOI: 10.1016/S0928-0987(98)00010-4.

8. P. Hainey, I. M. Huxham, B. Rowatt, D. C. Sherrington and L. Tetley, Synthesis and ultrastructural studies of styrene-divinylbenzene polyhipe polymers, Macromolecules 24 (1991) 117-121; DOI: $10.1021 / \mathrm{ma} 00001 \mathrm{a} 019$.

9. M. S. Muthu and S. Singh, Poly (d, 1-lactide) nanosuspensions of risperidone for parenteral delivery: formulation and in-vitro evaluation, Curr. Drug Deliv. 6 (2009) 62-68; DOI: 10.2174/ 156720109787048302.

10. T. Higuchi, Rate of release of medicaments from ointment bases containing drugs in suspension, J. Pharm. Sci. 50 (1961) 874-875; DOI: 10.1002/jps.2600501018.

11. L. Panigrahi, S. K. Ghosal, S. Pattnaik, L. Maharana and B. B. Barik, Effect of permeation enhancers on the release and permeation kinetics of lincomycin hydrochloride gel formulations through mouse skin, Indian J. Pharm. Sci. 68 (2006) 205-211; DOI: 10.4103/0250-474X.25716.

12. R. Kumar, M. B. Patil, S. R. Patil and M. S. Paschapur, Evaluation of Anacardium occidentale gum as gelling agent in aceclofenac gel, Int. J. PharmTech. Res. 1 (2009) 695-704.

13. M. I. Re and B. Biscans, Preparation of microspheres of ketoprofen with acrylic polymers by a quasi-emulsion solvent diffusion method, Powder Technol. 101 (1999) 120-133; DOI: 10.1016/ S0032-5910(98)00163-6.

14. J.-H. Lee, T. G. Park and H. K. Choi, Development of oral drug delivery system using floating microspheres, J. Microencapsul. 16 (1999) 715-729; DOI: 10.1080/026520499288663.

15. A. Nokhodchi, M. Jelveghari, M. -R. Siahi and S. Dastmalchi, The effect of formulation type on the release of benzoyl peroxide from microsponges, Iranian J. Pharm. Sci. 1 (2005) 131-142.

16. T. K. Mandal, L. A. Bostanian, R. A. Graves, S. R. Chapman and T. U. Idodo, Porous biodegradable microparticles for delivery of pentamidine, Eur. J. Pharm. Biopharm. 52 (2001) 91-96; DOI: 10.1016/S0939-6411(01)00150-3.

17. M. Kılıçarslan and T. Baykara, The effect of the drug/polymer ratio on the properties of verapamil HCl loaded microspheres, Int. J. Pharm. 252 (2003) 99-109; DOI: 10.1016/S0378-5173(02) 00630-0.

18. P. Piyakulawat, N. Praphairaksit, N. Chantarasiri and N. Muangsin, Preparation and evaluation of chitosan/carrageenan beads for controlled release of sodium diclofenac, AAPS PharmSciTech. 8 (2007) 120-130; DOI: 10.1208/pt0804097.

19. S. Puttipipatkhachorn, T. Pongjanyakul and A. Priprem, Molecular interaction in alginate beads reinforced with sodium starch glycolate or magnesium aluminum silicate, and their physical characteristics, Int. J. Pharm. 293 (2005) 51-62; DOI: 10.1016/j.ijpharm.2004.12.006. 
S. Maiti et al:: Development and evaluation of xanthan gum-facilitated ethyl cellulose microsponges for controlled percutaneous delivery of diclofenac sodium, Acta Pharm. 61 (2011) 257-270.

$S A \check{Z} E T A K$

\section{Razvoj i vrednovanje mikrospužvastih sustava etilceluloze i ksantan gume za kontroliranu perkutanu isporuku diklofenak natrija}

SABYASACHI MAITI, SANTANU KAITY, SOMASREE RAY i BISWANATH SA

U radu su opisani mikrospužvasti sustavi s etilcelulozom i ksantan gumom pripravljeni metodom dvostruke emulzifikacije i dispergirani u podlogu s karbopol gelom za kontrolirano oslobađanje diklofenak natrija na kožu. Elektronska pretražna mikroskopija potvrdila je poroznu, sferičnu strukturu mikrospužvastih sustava. Povećanjem omjera lijeka i polimera $(0,4: 1,0,6: 1,0,8: 1, \mathrm{~m} / \mathrm{m})$ povećalo se iskorištenje $(79,1-88,5 \%)$, količina uklopljenog lijeka (50,0-64,1 \%) i srednji promjer čestica $(181-255 \mu \mathrm{m})$. Prolaz uklopljenog lijeka kroz izrezane komade kože štakora smanjio se za 19,9 \%, odnosno 17,0 \%, kada se omjer lijeka i polimera smanjio s visokog $(0,8: 1, \mathrm{~m} / \mathrm{m})$ na niski i srednji. Oslobađanje iz mikrospužvastih struktura s omjerom lijeka i polimera 0,8:1 ( $\mathrm{m} / \mathrm{m})$ smanjeno je za $33,3 \%$ u odnosu na oslobađanje ekvivalentne količina lijeka koji nije uklopljen već samo dispergiran u geliranu podlogu. Ako je lijek bio dispergiran kao neuklopljen ili kao uklopljen u geliranu podlogu, permeacija lijeka kroz kožu štakora slijedila je Higuchijev difuzijski kinetički model. Mikrospužvaste strukture pripravljene uz najniži omjer lijeka i polimera pokazale su sporiji permeacijski profil pa ih smatramo najpovoljnijima za kontrolirano oslobađanje lijeka. FTIR spektroskopija i DSC analiza pokazale su da je lijek u mikrospružvastim sustavima stabilan i amorfan. Gel s optimiranim mikrospužvastim sustavom sličan je komercijalnom gelu i ne pokazuje ozbiljne kožne reakcije. Sustav pripravljen s najnižim omjerom lijeka i polimera mogao bi biti pogodan za kontrolirano oslobađanje diklofenak natrija na kožu.

Ključne riječi: W/O/W emulzija, mikrospužvaste strukture, diklofenak natrij, ksantan guma, etilceluloza, perkutana isporuka 